\title{
ANALISIS KELAYAKAN INVESTASI PEMBIAKAN DOMBA DI KECAMATAN GUNUNGHALU KABUPATEN BANDUNG BARAT
}

\section{Feasibility Study Sheep Breeding in Gununghalu District Bandung Barat Regency}

\author{
Cecep Firmansyah ${ }^{1}$, Sondi Kuswaryan ${ }^{2}$, Andre Rivianda Daud ${ }^{3}$ \\ ${ }^{1,2,3}$ Fakultas Peternakan Universitas Padjadjaran \\ Email : Cepfirmansyah@gmail.com
}

\begin{abstract}
ABSTRAK
Penelitian ini bertujuan untuk mengetahui kelayakan pengembangan pembiakan domba di Kecamatan Gununghalu. Penelitian dilaksanakan dengan menggunakan metode survey. Responden penelitian sebanyak 30 orang yang diambil dengan menggunakan teknik cluster random sampling dan dilanjutkan dengan simple random sampling. Hasil penelitian menunjukan bahwa : (a) skala usaha dalam usaha pembiakan adalah 10 ekor domba betina dan satu ekor pejantan, (b) Usaha pembiakan domba memberikan keuntungan kepada pelaku usaha, dan berbagai parameter investasi menujukan bahwa usaha pembiakan domba di Kecamatan Gununghalu layak dijalankan.
\end{abstract}

Kata Kunci: Kelayakan, pembiakan, domba

\begin{abstract}
This study aims to determine the feasibility of developing sheep breeding in Gununghalu District. The study was conducted using survey methods. Research respondents were 30 people taken using cluster random sampling techniques and continued with simple random sampling. The results showed that: (a) the scale of business in breeding business was 10 head ewes and one head ram, (b) sheep breeding business gave benefits to business actors, and various investment parameters aimed that the sheep fattening business in Gununghalu District was feasible.
\end{abstract}

Keywords: feasibility, breeding, sheep 


\section{A. PENDAHULUAN}

Usahaternak domba banyak diselenggaakan oleh masyarakat perdesaan di Jawa Barat, termasuk di Kabupaten Bandung Barat. Kegiatan usaha ternak domba di perdesaan umumnya merupakan bagian dari kegiatan pertanian untuk memanfaatkan waktu luang, karena kegiatan pertanian bersifat musiman. Usaha ternak domba di kabupaten ini belum menjadi usaha pokok, dengan tujuan untuk mendapatkan penghasilan tambahan, serta ternak domba menjadi asset yang sewaktu-waktu dapat diuangkan untuk memenuhi kebutuhan ekonomi rumah tangga dalam keadaan mendesak.

Kecamatan Gununghalu dalam rencana tataruang (RTRW) merupakan salah satu wilayah yang direncanakan menjadi kawasan budidaya (pertanian peternakan), komoditas yang akan dikembangkan salah satunya adalah ternak domba. Pembangunan sektor peternakan termasuk pengembangan ternak domba diharapkan oleh pemerintah KBB dapat memberikan konstribusi yang berarti terhadap pembangunan daerah, khususnya dalam upaya meningkatkan perekonomian perdesaan melalui peningkatan lapangan pekerjaan dan lapangan usaha.

Sektor usaha apabila akan didirikan, dikembangkan dan diperluas maupun dilikuidasi selalu didahului dengan satu kegiatan yang disebut studi kelayakan. Bahkan di beberapa departemen instansi pemerintah untuk mengusulkan proyek harus disertai dengan studi kelayakan. Apalagi di sektor industri dan perdagangan, yang lebih bersifat komersial dan padat modal. Kekeliruan dan kesalahan dalam menilai investasi akan menyebabkan kerugian dan resiko yang besar. Penilaian investasi terdapat dalam studi kelayakan yang bertujuan untuk menghindari terjadinya keterlanjuran investasi yang tidak menguntungkan karena usaha yang tidak feasible, untuk itu dalam perluasan dan pengembangan kegiatan domba di Kabupaten Bandung Barat diperlukan penyusunan studi kelayakan.
Penelitian ini bertujuan untuk mengetahui kelayakan pengembangan usaha ternak domba di wilayah Kecamatan Gununghlau Kabupaten Bandung Barat. Kelayakan usaha yang dimaksud adalah kelayakan financial berdasarkan parameter investasi

\section{B. MATERI DAN METODE}

Objek dalam penelitian ini adalah usaha pembiakan domba, dan subjeknya adalah peternak domba yang melaksanakan pembiakan domba.

Metode penelitian yang digunakan adalah survey ang dilaksanakan pada peternakan domba skala rakyat di wilayah Kecamatan Gununghalu Kabupaten Bandung Barat.. Lokasi ditentukan secara purposive dengan pertimbangan bahwa wilayah tersebut oleh PEMDA Kabupaten Bandung Barat dicanagkan sebagai salah satu wilayah pengembangan ternak domba, sehingga membuthkan kajian awal untuk pengembangan domba di wilayah tersebut, dan di wilayah tersebut terdapat banyak peternak domba yang melaksanakan pembiakan domba. Jumlah responden dalam penelitian ini sebanyak 30 orang menggunakan metode cluster random sampling dan dilanjutkan dengan simple random sampling.

Model analisis yang digunakan adalah analisis kelayakan investasi. Parameter investasi yang menjadi indicator kelayakannya adalah NPV, IRR, Gross BC, Net BC, Payback Perode, serta Break Event Point (BEP).

\section{HASIL DAN PEMBAHASAN}

a. Kondisi Wilayah

Kecamatan Gununghalu Kabupaten Bandung Barat. Kecamatan ini terletak pada $7^{\circ} 2^{\prime} 42.17^{\prime \prime}$ LS dan $107^{\circ} 19^{\prime} 27.43^{\prime \prime}$ BT berada pada ketinggian 1.146 meter dari permukaan laut. Kondisi suhu lingkungan berkisar antara $22-30$ ${ }^{0} \mathrm{C}$ dan kelembaban rata-rata $76 \%$. Curah hujan sekitar 222,1 mm per tahun dengan jumlah hujan 8 bulan. Kedua variable iklim ini memberikan 
gambaran relative baik untuk pertumbuhan dan perkembangan vegetasi, khususnya rumput sebagai sumber pakan, dan baik untuk kegiatan pertanian padi dan palawija yang juga menghasilkan limbah dan sisa hasil pertanian yang dapat dijadikan pakan domba.

Domba sebagai salah satu ternak ruminansia yang makanan utamanya adalah rumput yang berasal dari lahan pertanian, perkebunan dan kehutanan atau lahan terbuka lainnya. Dengan demikian pengembangan usaha domba membuthkan lahan sebagai basis produksi pakan, dan untuk perkandangannya. Pengembangan usaha pembiakan domba juga perlu memperhatikan kondisi lingkungan, aksesibilitas dan sarana dan prasarana yang menunjang proses usaha berjalan lancar, efisien, berkesinambungan dan produknya berdaya saing di pasaran. Secara umum lingkungan Kecamatan Gununghalu relative memberi dukungan terhadap kebutuhan ternak domba dan usahanya, namun karena pengembangan usaha pembiakan domba harus berkesinambungan, maka perlu di kaji apakah wilayah desa-desa yang ada di kecamata tersebut memiliki kesesuaian untuk pengembangan ternak domba, ditinjau dari kriteria kesesuaian lingkungan.

Beberapa criteria yang berhasil diidentikasi dan dikuantifikasi memberikan gambaran bahwa terdapat desa yang kepedatan penduduknya masih rendah sehingga menjadi peluang bagi pengembangan domba. Jumlah penduduk yang memiliki mata pencaharian dalam kegiatan bertani relative banyak yaitu di Desa Gununghalu, Cilangri. Sukasari di atas 3.000 orang, jumlah ini mengindikasikan adanya kultur bertani dan beternak, karena pada umumnya orang yang beternak domba juga berprofesi sebagai petani atau buruh tani. Nisbah lahan pangan dengan penduduk menandakan penguasaan lahan dan secara tidak langsung merupakan gambaran potensi pakan dari lahan tersebut dan limbah serta sisa hasil pertanian (karena tidak diperoleh data tatagunalahan), maka diolah berdasarkan luas wilayah, terdapat 3 desa yang nisbah lahannya relative besar yaitu Desa Gununghalu, Cilangri dan Sukasari. Lembaga atau kelompok yang bergerak dalam bidang peternakan domba, seperti kelompok peternak, HPDKI dinilai dapat memberikan iklim terhadap tumbuhkembangnya peternakan domba pada masing-masing desa. Di setiap wilayah desa umumnya terdapat kelompok peternak dengan jumlah paling banyak adalah di Desa Sinarjaya, Gununghalu, Sukasari dan Tamanjaya.

Hasil analisis terhadap berbagai criteria menunjukan bahwa tingkat kesesuaian wialayah desa terhadap pengembanagan usaha pembiakan domba relative berbeda. Dari sembelan desa hanya ada satu desa yang dengan kategori S1 atau "sangat sesuai (highly sitable) yaitu Desa Gununghalu. Pengembangan pembiakan domba di Desa Gununghalu berdasrkan hasil analisis tidak akan ada faktor pembatas yang secara signifikan berpengaruh negative terhadap pemborosan biaya, dan juga terhadap keberlanjutan usahanya. Tujuh dari 9 desa memiliki tingkat kesesuain S2 atau cukup sesuai (moderately suitable) untuk pengembangan domba, pada tingkat kesesuai S2 ini terdapat faktor yang menjadi faktor pembatas agak berat yang dapat berpengaruh terhadap pemborosan biaya, dan keberlanjutan usaha. Untuk wilayah desa pada tingkat kesesuain S2 perlu ada upaya yang dilakukan untuk mengurangi keterbatasan tersebut. Dan terdapat satu desa dengan tingkat kesesuaian S3 atau sesuai marjinal (marginal suitable) yaitu Desa Wargasaluyu, dimana pengembangan domba di desa tersebut terdapat faktor pembatas yang sangat berat untuk sustainability pengembangan sehubungan nisbah lahan pangan terhadap penduduk relative lebih kecil dari desa lainnay, kepadatan penduduk relative tinggi, dan ada keterbatasan kelembagaan sebagai fasilitas layanan yang berhubungan dengan peternakan. (Tabel 1). 
Tabel 1. Kepadatan Penduduk, Matapencaharian, Nisbah Lahan dan Kelembagaan Menurut Desa di Kecamatan Gununghalu Kabupaten Bandung Barat

\begin{tabular}{clcccc}
\hline No & Nama Desa & $\begin{array}{c}\text { Kepadatan } \\
\text { Penduduk } \\
\text { (orang/km }\end{array}$ & $\begin{array}{c}\text { Matapencaharian } \\
\text { bertani } \\
\text { (orang) }\end{array}$ & $\begin{array}{c}\text { Nisbah } \\
\text { Lahan/penduduk } \\
(\%)\end{array}$ & $\begin{array}{c}\text { Lembaga/ } \\
\text { Kelompok Domba } \\
\text { (buah) }\end{array}$ \\
\hline 1 & Cilangari & 998 & $\mathbf{4 , 4 5 0}$ & $\mathbf{1 3 . 9 0}$ & 3 \\
2 & Sindangjaya & $\mathbf{2 2 3}$ & $\mathbf{2 , 5 6 0}$ & 8.63 & 3 \\
3 & Bunijaya & $\mathbf{6 4 2}$ & 1,691 & 5.70 & 6 \\
4 & Sirnajaya & $\mathbf{3 4 6}$ & $\mathbf{2 , 2 2 2}$ & 7.49 & $\mathbf{1 2}$ \\
5 & Gununghalu & $\mathbf{2 6 0}$ & $\mathbf{4 , 8 3 2}$ & $\mathbf{1 6 . 2 8}$ & $\mathbf{8}$ \\
6 & Celak & 1,012 & $\mathbf{2 , 4 7 2}$ & 8.33 & 6 \\
7 & Wargasaluyu & 1,117 & 1,107 & 3.73 & $\mathbf{8}$ \\
8 & Sukasari & 791 & $\mathbf{3 , 7 8 0}$ & $\mathbf{1 2 . 7 4}$ & $\mathbf{8}$ \\
9 & TamanJaya & $\mathbf{6 1 3}$ & $\mathbf{2 , 4 6 0}$ & 8.29 & \\
\hline
\end{tabular}

\section{b. Analisis Usaha Pembiakan Domba}

Skala pembiakan domba dalam satu unit usaha yang dikelola oleh satu atau beberapa orang peternak adalah sebanyak 10 ekor dengan satu ekor pejantan. Pelaku usaha pembiakan domba adalah para peternak yang tergolong pada kategori smallholders. Usaha yang akan mereka garap dalam rancangannya ditunjang dengan peningkatan kapasitas kemampuan peternak untuk mengatasi keterbatasan terhadap akses sumberdaya lahan, akses permodalan, serta akses pasar sebagai langkah meningkatkan produktivitas dan manfaat (benefit), baik manfaat financial maupun manfaat ekonomi dari perannya sebagai pelaku usaha.

Investasi adalah penanaman modal dalam suatu kegiatan yang memiliki jangka waktu relatif panjang dalam berbagai bidang usaha (Kasmir dan Jakfar, 2012). Investasi bertujuan untuk memperoleh keuntngan financial dan manfaat social. Investasi dalam usaha pembiakan domba di Kecamatan Gununghalu dibutuhkan untuk pengadaan real asset sebagai investasi tetap, dan biaya operasional awal sebagai modal kerja dengan tujuan memperoleh keuntungan financial, dan memperoleh manfaat social (social benefit) atau manfaat ekonomi (economic benefit) berupa nilai tambah dari pemanfaatan
Tabel 2. Proyeksi Kebutuhan Investasi

\begin{tabular}{clrr}
\hline No. & \multicolumn{1}{c}{ Uraian } & Jumlah & $\begin{array}{c}\text { Proporsi } \\
(\mathbf{\%})\end{array}$ \\
\hline 1 & INVESTASI TETAP & & \\
& Sewa Lahan & 750,000 & 1.30 \\
& Kandang & $17,550,000$ & 30.51 \\
& Peralatan & $1,837,500$ & 3.19 \\
& Pembelian Domba & & 0.00 \\
& Induk & $22,000,000$ & 38.25 \\
& Pejantan & $2,700,000$ & 4.69 \\
& Sub Total & $\mathbf{4 4 , 8 3 7 , 5 0 0}$ & $\mathbf{7 7 . 9 6}$ \\
MODAL KERJA & & 0.00 \\
& Pakan & $9,108,000$ & 15.84 \\
& Vitamin \& Obat-obatan & 329,040 & 0.57 \\
& Tenaga Kerja Kandang & $3,240,000$ & 5.63 \\
& Sub Total & $\mathbf{1 2 , 6 7 7 , 0 4 0}$ & $\mathbf{2 2 . 0 4}$ \\
\hline \multirow{2}{*}{3} & TOTAL INVESTASI & $\mathbf{5 7 , 5 1 4 , 5 4 0}$ & 100.00 \\
\hline
\end{tabular}

Kebutuhan dana awal untuk menjalankan usaha ini sebesar Rp 57,51 juta Alokasi dana terbesar adalah untuk pengadaan real asset yang tergolong asset tetap, dan sebagian lagi untuk biaya operasional terutama untuk pembiayaan yang tergolong biaya variable sampai usaha itu mampu menhasilkan peneriamaan yang dapat digunakan untuk membayar seluruh pengeluaran yang dibutuhkan (Tabel 2). 
Tabel 3. Proyeksi Biaya dan Manfaat Usaha Pembiakan Domba Skala 10 Ekor Induk

\begin{tabular}{|c|c|c|c|c|c|c|}
\hline \multirow{2}{*}{ No } & \multirow{2}{*}{ Uraian } & \multicolumn{5}{|c|}{ Tahun } \\
\hline & & 1 & 2 & 3 & 4 & 5 \\
\hline $\mathbf{A}$ & BENEFIT & & & & & \\
\hline 1 & Penjualan Domba & - & $18,650.00$ & $57,600.00$ & $45,850.00$ & $107,350.00$ \\
\hline \multirow[t]{2}{*}{2} & Salvage Value & - & - & - & - & $76,527.50$ \\
\hline & Total Benefit & - & $18,650.00$ & $57,600.00$ & $45,850.00$ & $183,877.50$ \\
\hline B & BIAYA & & & & & \\
\hline 1 & Biaya Tetap & $44,837.50$ & - & $24,700.00$ & - & - \\
\hline \multirow[t]{2}{*}{2} & Biaya Variabel & $15,917.04$ & $18,294.39$ & $26,913.92$ & $40,710.07$ & $45,411.00$ \\
\hline & Total Biaya & $60,754.54$ & $18,294.39$ & $51,613.92$ & $\mathbf{4 0 , 7 1 0 . 0 7}$ & $\mathbf{4 5 , 4 1 1 . 0 0}$ \\
\hline $\mathbf{C}$ & NET BENEFIT & $(60,754.54)$ & 355.61 & $5,986.08$ & $5,139.93$ & $138,466.50$ \\
\hline
\end{tabular}

Analisis kelayakan investasi dilakukan dalam kurun waktu 5 tahun, sehingga dalam rentang waktu tersebut diperkirakan akan mengalami berbagai perubahan. Fakta menunjukan bahwa dari tahun ke tahun dalam perekonomian nasional maupun global cenderung terjadi inflasi sebagai akibat adanya kenaikan harga barang. Data BPS yang dirilis website https://www.kemenkeu.go.id/ menyebutkan bahwa tingkat inflasi tahun kalender (JanuariAgustus) 2019 sebesar 2,48 persen dan tingkat inflasi tahun ke tahun (Agustus 2019 terhadap Agustus 2018) sebesar 3,49 persen. Tingkat inflasi secara langsung akan mendorong penurunan daya beli.

Tujuan investasi diantaranya adalah memperoleh manfaat dari sejumlah dana yang diinvestasikan, manfaat yang dimaksud dapat berupa margin atau keuntungan dari sejumlah investasi, juga bisa dalam bentuk benefit social seperti dalam peternakan adalah untuk pelestarian sumberdaya genetic, peningkatan populasi ternak, meningkatkan perekonomian perdesaan dan penciptaan lapangan pekerjaan. Apapun tujuannya, investasi adalah penanaman modal pada sebuah kegiatan, dimana kegiatan tersebut mengandung risiko yaitu : uang yang diinvestasikan kemunkinan tidak dapat kembali sebagian bahkan seluruhnya, dan kalau pun seluruh dana investasi dapat kembali, namun nilai riil atau daya beli uang yang diinvestasikan sudah menurun. Secara teoritis, penggunaan dana investasi dalam sebuah kegiatan tidak terlepas dari biaya, biaya penggunaan uang investasi merupakan social opportunity cost of capital (SOCC) dan biasanya dalam studi kelayakan nilai SOCC dijadikan dasar untuk memperhitungkan faktor diskonto (discount factor). Berdasarkan hal itu maka dalam pengukuran kelayakan investasi usahaternak domba menggunakan faktor diskonto (discount factor) atau faktor penguang. Faktor diskonto yang digunakan adalah nilai bunga modal pinjaman sebesar $12 \%$ per tahun, sehubungan pada bunga pinjaman tersebut sudah terkandung risiko akibat inflasi, risiko pinjaman tidak kembali, dan jasa pengelolaan keuangan.

Usaha pembiakan domba skala 20 ekor per unit usaha selama lima tahun di bawah asumsi teknis, zooteknis, asumsi financial, asumsi ekonomi yang digunakan dalam perhitungan menujukan hasil sebagai berikut :

a. Usaha pembiakan sapi potong mempeoleh total keuntungan bersih saat ini (net present value) yang positif, hal ini menujukan bahwa present value benefit (PVB) lebih besar dari present value cost (PVC), artinya usaha pembiakan domba skala 10 ekor betina dan 1 ekor pejantan dinilai menguntungkan.

b. Hasil pengukuran IRR menunjukan bahwa usaha pembiakan domba memiliki 
kemampuan dalam mengembalikan bunga modal. Usaha ini baru mengalami impas atau penerimaan (TR) sama dengan total biaya (TC) pada penggunaan beban bunga modal sebesar 26,43 \%, atau dengan pengertian lain usaha ini dapat dibiayai dengan dana kredit bunga komersil.

c. Gross benefit cost ratio (Gross B/C) atau yang dikenal secara umum $\mathrm{BC}$ rasio untuk usaha yang dianalisis memberikan gambaran bahwa benefit atau penerimaan usaha lebih besar dari pengeluaran (cost) sehingga imbangannya lebih besar dari 1 (satu). Nilai gross B/C usaha pembiakan domba memberikan gambaran bahwa dari sejumlah biaya yang dikeluarkan akan menghasilkan penerimaan sebesar $141 \%$, atau memperoleh laba sekitar $41 \%$.

d. Net B/C menujukan imbangan nilai keuntungan dengan nilai kerugian selama periode analisis. Hasil pengukuran menujukan bahwa ratio tersebut bernilai positif, yang berarti ini memberikan indikasi bahwa usaha ini mampu menghasilkan keuntungan.

Hasil analisis criteria investasi dapat dilihat pada Tabel 4.

Tabel 4. Kelayakan Investasi

\begin{tabular}{clr}
\hline No & Parameter & \multicolumn{1}{c}{ Nilai } \\
\hline 1 & NPV (Rp. Juta) & $32,135,269$ \\
2 & IRR (\%) & 26.43 \\
3 & GROSS B/C & 1.41 \\
4 & Net B/C & 2.47 \\
\hline
\end{tabular}

\section{KESIMPULAN DAN SARAN}

1. Skala usaha pembiakan domba per unit usaha adalah 10 ekor betina dengan satu ekor pejantan.

2. Usaha pembiakan domba memberikan keuntungan kepada pelaku usaha, dan berbagai parameter investasi menujukan bahwa usaha pembiakan domba di Kecamatan Gununghalu layak dijalankan

\section{DAFTAR PUSTAKA}

Ibrahim, Y. 2003. Studi Kelayakan Bisnis. Jakarta : Rineka Cipta. 133-134, 142-155.

Kasmir dan Jakfar. 2009. Studi Kelayakan Bisnis. Jakarta : Kencana Prenada Media Grup.

KBB, Rencana Program Investasi Jangka Menengah (RPIJM) Kabupaten Bandung Barat Tahun 2015-2019

Nurmi, A. 2016. Respons Fisiologis Domba Lokal dengan Perbedaan Waktu Pemberian Pakan Dan Panjang Pemotongan Bulu. Jurnal Eksakta Volume 1, 2016.

Umar H. 2007. Studi Kelayakan Bisnis. Edisi Ketiga. Jakarta : Gramedia Pustaka Utama

Undang-undang republik indonesia nomor 18 tahun 2012 Tentang pangan. www.bpkp.go.id Accessed 08/12/ 2019:10:05

Yuzmi Z. 2014. Kelayakan Bagi Hasil Usaha Ternak Domba Rakyat (Sensus di Kawasan Peternakan Domba Kecamatan Cikedung Kabupaten Indramayu). Jurnal : Fakultas Peternakan, Universitas Padjadjaran. 